\title{
Opioids increase bladder cancer cell migration via bradykinin B2 receptors
}

\author{
DESPOINA VASSOU ${ }^{1}$, GEORGE NOTAS ${ }^{1}$, ANASTASSIA HATZOGLOU ${ }^{1,2}$, \\ ELIAS CASTANAS $^{1}$ and MARILENA KAMPA ${ }^{1}$ \\ ${ }^{1}$ Laboratory of Experimental Endocrinology, University of Crete, \\ School of Medicine, Heraklion, Heraklion, GR-71110, Greece
}

Received December 9, 2010; Accepted January 17, 2011

DOI: $10.3892 /$ ijo.2011.1063

\begin{abstract}
Data relating opioid treatment and modification of cancer cell migration (a prerequisite of metastasis) both in vitro and in vivo are diverging. In the present report we show that opioids increase the migratory activity of bladder cancer cells (T24 and EJ) and we provide a new mechanistic insight, explaining (at least partially) their action: we report that the enhanced opioid-related cell migration is controlled (in the absence of opioid receptors) through their interaction with bradykinin B2 receptors. Indeed, in these cell lines, opioids increase migration, adhesion, spreading and invasion by re-arranging actin cytoskeleton, increasing MMP-2 and -9 secretion and triggering specific intracellular signaling cascades in a non-opioid receptor mediated manner. An interaction, albeit with low affinity, of opioids with the bradykinin B2 receptor is reported, resulting in the increase of migration, while B2 antagonists revert this action. A systematic assay of different human epithelial cancer cell lines confirmed that only the B2-positive/opioid receptornegative bladder cancer cells present this opioid-related increased migration/invasive phenotype. We suggest that opioid administration in cancer patients should be re-evaluated, keeping in mind that they may have other beneficial (protection) or adverse effects (spreading of cancer cells), in spite of their unique role in pain relief.
\end{abstract}

\section{Introduction}

A number of studies report that opioids (secreted endogenously or exogenously administered) are implicated in tumor growth,

Correspondence to: Dr M. Kampa, Laboratory of Experimental Endocrinology, University of Crete, School of Medicine, P.O. Box 2208, Heraklion, GR-71110, Greece

E-mail: kampa@med.uoc.gr

Present address: ${ }^{2}$ Universite Paul Sabatier, LBCMCP - CNRS UMR5088-IFR 109, Toulouse, France

Key words: migration, invasion, opioids, bladder cancer, bradykinin $\mathrm{B} 2$ receptor progression and metastasis $(1,2)$. Extensive work has been performed in the field of cancer cell proliferation and apoptosis; however, scarce, heterogeneous, or conflicting data occur, on opioid effect in cell motility and metastasis. Morphine was found to decrease tumor metastasis $(3,4)$, either through a direct action on colon cancer tumor cells $(5,6)$, or by attenuating stress $(3,4)$. Other opioids were found to increase cell motility and invasion of breast and small cell lung carcinoma $(7,8)$, or to have no effect (pancreatic, colon, and head and neck carcimona) (9). Conversely, very few indirect data concern opioid effects in the genitourinary system: Patel et al reported that opiate addiction results in progression of urogenital injury (10), while opioid agonists were shown to decrease cell proliferation of opossum kidney (OK) cells (11).

The majority of deaths in bladder cancer are due to tumor ability to invade the bladder wall and demonstrate a high propensity for lymphatic and distant metastases. In the present study we have investigated the direct action of opioids (with different receptor selectivity), on the metastatic potential (migratory activity, adhesion, spreading and invasion) of T24 and EJ bladder cancer cells. Our results indicate that opioids can increase the migration of bladder cancer cells, by triggering specific signaling cascades. Their action is not mediated by opioid receptors, but involves bradykinin B2 receptor activation, providing new insights into the role of opioids in malignancies.

\section{Materials and methods}

Reagents. Ethylketocyclazosine (EKC) was from Bayer (Leverkusen, Germany). $\alpha_{\mathrm{S} 1}$-casomorphine ( $\alpha_{\mathrm{S} 1}$, Tyr-Val-ProPhe-Pro) was synthesized by peptide chemistry methods (12). Diprenorphine was from Reckit\&Coleman Co, while morphine and naloxone were from Francopia (Paris, France). HOE 140 (bradykinin B2 receptor antagonist) and sodium orthovanadate (protein tyrosine phosphatase inhibitor) were from SigmaHellas (Athens, Greece). SB203580 (p38 kinase inhibitor), PD98058 (ERK1/2 inhibitor), wortmannin (PI3K inhibitor) and SP600125 (JNK inhibitor) were from Calbiochem (San Diego, CA). NG-nitro-L-arginine methyl ester hydrochloride (L-NAME, NOS inhibitor) and (S)-nitroso-N-acetylpenicillamine (SNAP, NO-donor) were from Tocris (Bristol, UK). [ $\left.{ }^{3} \mathrm{H}\right] \mathrm{U} 69,593$ (41.7 Ci/mmol), [ $\left.{ }^{3} \mathrm{H}\right] \mathrm{DAMGO}(56.8 \mathrm{Ci} / \mathrm{mmol}),\left[{ }^{3} \mathrm{H}\right] \mathrm{DPDPE}$ (25.2 Ci/mmol) and $\left[{ }^{3} \mathrm{H}\right]$ Bradykinin, [2,3-Prolyl-3,4- $\left.\left[{ }^{3} \mathrm{H}\right](\mathrm{N})\right]$ 
$(80 \mathrm{Ci} / \mathrm{mmol})$ were from Perkin Elmer (Waltham, MA). Bradykinin, DAMGO, DPDPE and U69,593, as well as all other chemicals, were from Sigma-Hellas.

Cell lines and culture conditions. T24 (bladder), MCF7 (breast), HepG2 (liver), HeLa (cervix) and SKOV-3 (ovary) human carcinoma cell lines were from the ATCC (Teddington, UK); EJ (bladder) cells was a gift from Dr A. Eliopoulos (University of Crete). T24, HeLa and SKOV-3 cells were grown in DMEM, MCF7 cells in DMEM/F12 and EJ and HepG2 cells in RPMI1640 medium, supplemented with $10 \%$ heat-inactivated fetal bovine serum (FBS) and $1 \%$ penicillin $(5,000 \mathrm{IU} / \mathrm{ml}) /$ streptomycin $(5,000 \mu \mathrm{g} / \mathrm{ml})$, in a humidified atmosphere of $5 \% \mathrm{CO}_{2}$, at $37^{\circ} \mathrm{C}$. Cell growth was measured by the MTT assay (13).

Migration assays. A linear scratch (200-500 $\mu \mathrm{m})$ was made with a sterile pipette tip at confluence-grown cells, in the absence or the presence of opioids or bradykinin $\left(10^{-6} \mathrm{M}\right)$ with or without a 10 times molar excess of specific opioid (Diprenorphine or Naloxone) or bradykinin antagonist (HOE 140, $10^{-7}-10^{-5} \mathrm{M}$ ), kinase- (SB203580 $25 \mu \mathrm{M}$, PD98059 $25 \mu \mathrm{M}$, Wortmannin $0.1 \mu \mathrm{M}$, or SP600125 $10 \mu \mathrm{M}$ ), or protein tyrosine phosphatase (sodium orthovanadate, $10^{-6} \mathrm{M}$ ) inhibitors. The subsequent colonization of the denuded area was quantified with an inverted microscope (DM IRE2, Leica), at different time-intervals.

Cell trans-migration was also evaluated using the Corning Transwell assay (Cambridge, UK). Cells $\left(2-5 \times 10^{4} / 100 \mu \mathrm{l}\right)$ were seeded in the upper side of an $8 \mu \mathrm{m}$ pore size polycarbonate membrane, with $300 \mu \mathrm{l}$ medium at the lower chamber and incubated for $24 \mathrm{~h}$ at $37^{\circ} \mathrm{C}$. Afterwards, cells were removed from the top surface, while underside (migrated) cells were stained with $0.2 \%$ crystal violet for $10 \mathrm{~min}$, solubilized in $30 \%$ acetic acid and absorbance was measured at $600 \mathrm{~nm}$.

Cell adhesion assay. Treated cells were washed, incubated in serum-free medium for $30 \mathrm{~min}$, resuspended in serum-free medium, seeded on $96-$ well plates coated with $10 \mu \mathrm{g} / \mathrm{ml}$ collagen type I (100 $\mu \mathrm{l} /$ well), pre-incubated for $90 \mathrm{~min}$ at $37^{\circ} \mathrm{C}$, at a density of $2 \times 10^{4}$ for $\mathrm{T} 24$ and $3 \times 10^{4}$ cells per well for the other cell lines and allowed to adhere for different time intervals $(15-120 \mathrm{~min})$ at $37^{\circ} \mathrm{C}$. Adherent cells were stained with $0.1 \%$ crystal violet in $20 \%$ methanol for $10 \mathrm{~min}$ and lysed with $1 \%$ SDS. The absorbance $(600 \mathrm{~nm})$ was proportional to the number of cells (14).

Cell spreading. Cells were seeded on 6-well collagen I-coated plates. After $2 \mathrm{~h}\left(37^{\circ} \mathrm{C}\right)$, adherent cells were fixed with $3.7 \%$ formaldehyde for $10 \mathrm{~min}$ and spreading was quantified with an inverted microscope. Photographs were analyzed using the Image J program (NIH, Bethesda, MD, USA) on an average of $\sim 700$ cells per condition.

Invasion assay. Cell invasion was assayed using the $\mathrm{QCM}^{\mathrm{TM}}$ Cell Invasion Assay (Milipore, Labsuplies, Athens, Greece): Cells $\left(5 \times 10^{4}\right.$ cells per well) were re-suspended in serum-free medium on the extracellular matrix-coated inserts $(8 \mu \mathrm{m}$ pore size), while $150 \mu \mathrm{l}$ medium was added to the lower chamber. After $24 \mathrm{~h}$, invading cells were detached from the bottom side of the insert, lysed, stained and fluorescence was measured with microplate fluorescence reader using a 485/528 $\mathrm{nm}$ filter set (FLX800, BIO-TEK Instruments Inc. VT).

Confocal laser scanning microscopy for actin cytoskeleton detection. Cells growing on poly-L-lysine coated coverslips, were fixed ( $4 \%$ paraformaldehyde, $10 \mathrm{~min}$ ), permeabilized $(0.5 \%$ Triton X-100, $10 \mathrm{~min}$ ), stained with rhodamine-labeled phalloidin (45 min), mounted with mounting medium (IMMCO Diagnostics, Buffalo, NY) and visualized with a confocal laser-scanning module (Leica Lasertechnik, Heidelberg, Germany) attached to a microscope (Zeiss IM35, Zeiss, Oberkochen, Germany). Cortical filamentous actin (F-actin) to total F-actin ratio was calculated with the aid of Image J program, on an average of 15 cells per condition.

Assay of MMP-2 and -9 secretion by gelatin zymography. Aliquots of culture conditioned media were electrophoresed in $0.5 \mathrm{mg} / \mathrm{ml}$ gelatin type $\mathrm{A} / 10 \%$, SDS polyacrylamide gels, under denaturing/non-reducing conditions $(80 \mathrm{~V})$. Gels were washed with $2.5 \%$ Triton X-100 solution ( $1 \mathrm{~h})$, incubated at $37^{\circ} \mathrm{C}$ overnight in a gelatinase activation buffer $(0.1 \mathrm{M}$ Tris-HCl, pH 7.4, $5 \mathrm{mM} \mathrm{CaCl}_{2}, 200 \mathrm{mM} \mathrm{NaCl}, 0.02 \%$ Brij 35) and stained with $0.5 \%$ Coomassie Brilliant Blue in $40 \%$ methanol/ $10 \%$ acetic acid. After intensive de-staining, proteolysed areas appeared as clear bands against a blue background (15). Photographs were analyzed using the Image J program (NIH, Bethesda, MD, USA). In all cases, data were normalized per number of cells in each experiment.

\section{Opioid and bradykinin receptor assays}

Binding assays. Binding was performed in whole cells $\left(10^{6}\right.$ cells/ well), in a total volume of $0.4 \mathrm{ml}$ serum-free medium, containing radioactive opioid or bradykinin $(\sim 2.5 \mathrm{nM})$ and $2 \mathrm{mM}$ bacitracin, without (total binding) or with (non-specific binding) a thousand-fold molar excess of the same unlabelled agent $(2 \mathrm{~h}$ at room temperature for opioids and $3 \mathrm{~h}, 4^{\circ} \mathrm{C}$ for $\mathrm{BK}$ ). Unbound radioactivity was eliminated by washing with cold PBS. Cells were removed from plates with $0.5 \mathrm{ml} 2 \mathrm{~N} \mathrm{NaOH}$, and mixed with $3 \mathrm{ml}$ scintillation cocktail and radioactivity counted, with a $60 \%$ efficiency for Tritium. The following conditions were used for the detection of each opioid site: $\delta$ opioid sites were detected with $\left[\mathrm{H}^{3}\right] \mathrm{DPDPE}$; $\mathrm{Mu}$ sites with $\left[\mathrm{H}^{3}\right] \mathrm{DAMGO}$, while $\kappa$ sites were identified with $\left[\mathrm{H}^{3}\right] \mathrm{U} 69,593$ (11).

$R T-P C R$. Total cellular RNA was isolated with TRIzol (Invitrogen) and treated with DNase I. cDNA was synthesized with reverse transcriptase (SuperScript II RT, Invitrogen). RNA $(1 \mu \mathrm{g})$ was added to a mixture that contained $5 \mu \mathrm{M}$ oligo d(T)12-18 primers, $0.5 \mathrm{mM}$ dNTPs, $1 \mathrm{X}$ RT buffer, $5 \mathrm{mM}$ dithiothreitol (DTT), 2.5 units RNase OUT, and 10 units SuperScript II RT in a total volume of $20 \mu \mathrm{l}\left(42^{\circ} \mathrm{C}, 60 \mathrm{~min}\right)$. The PCR reaction mix included $1 \mu \mathrm{l}$ cDNA, 1 unit Dynazyme II (Finnzymes, Espoo, Finland), and $200 \mu \mathrm{M}$ dNTP mix, $2 \mathrm{mM}$ $\mathrm{MgCl}_{2}$, and $500 \mathrm{nM}$ gene-specific primers in a final volume of $25 \mu \mathrm{l}$. The conditions for PCR (Primus $96{ }^{\circledR}$ Advanced Gradient, PeqLab-Biotechnologie, Erlangen, Germany) were denaturation at $94^{\circ} \mathrm{C}$ for $5 \mathrm{~min}$, followed by 35 cycles of $0.5 \mathrm{~min}$ at $94^{\circ} \mathrm{C}$; annealing, $0.5 \mathrm{~min}$ at $57.5^{\circ} \mathrm{C}$ and extension, $1 \mathrm{~min}$ at $72^{\circ} \mathrm{C}$. The primers used were: $\kappa$-Opioid Receptor (sense: $5^{\prime}-\mathrm{CGT}$ CTC AAG AGC GTC CG-3' and antisense: 5'-TAT GTG AAT 

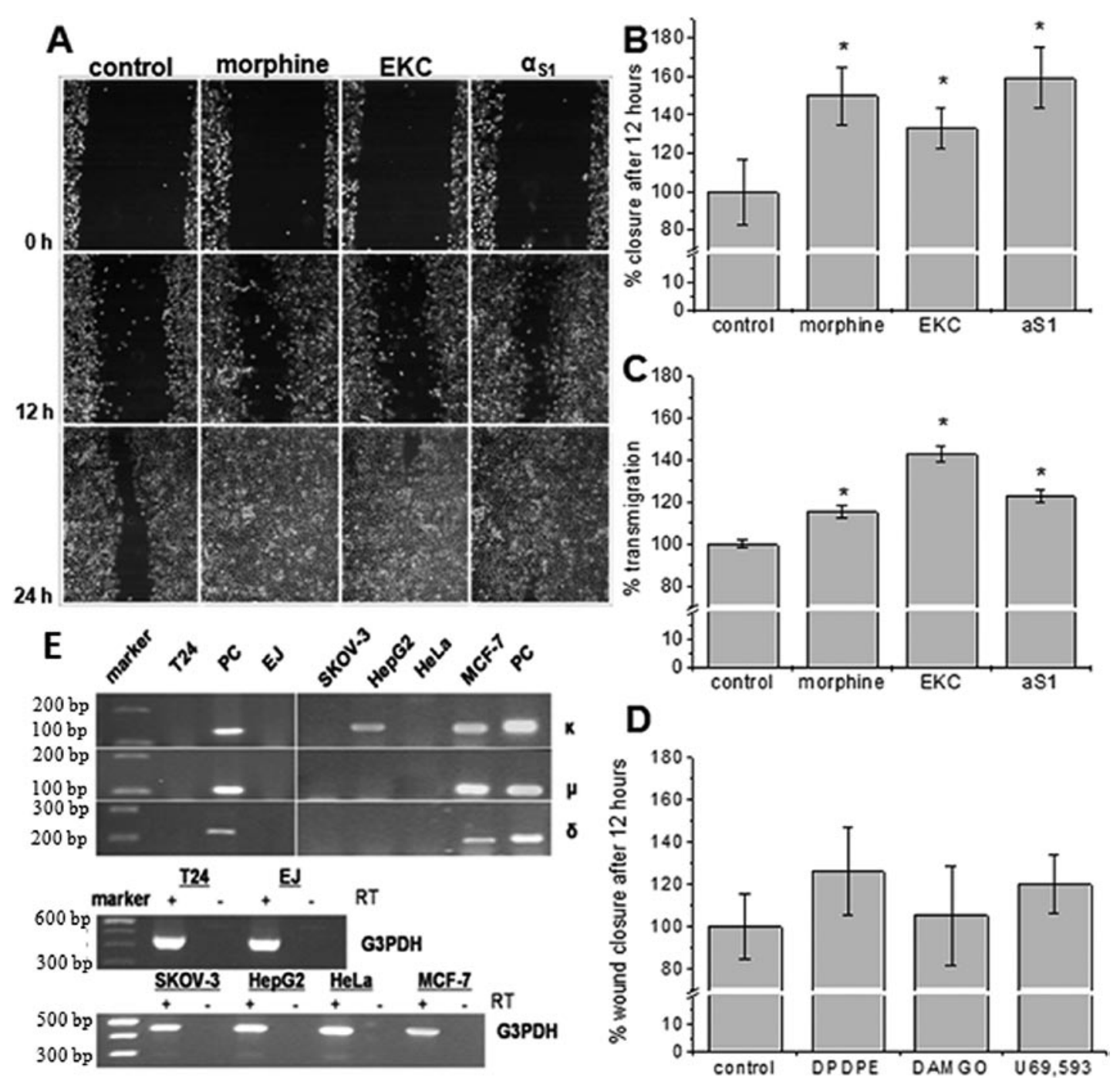

Figure 1. Effect of opioids on cell migration. Repair of wounds in monolayers of T24 cells in the presence or absence of opioids (morphine, EKC and $\alpha_{\mathrm{S} 1}, 10^{-6} \mathrm{M}$ ). (A) Representative photographed area of wound healing after 0,12 and $24 \mathrm{~h}$. (B) Quantification of the wound-healing process, after $12 \mathrm{~h}$ of incubation with opioids. Wound healing of control (untreated cells) is considered 100\%. (C) Histogram showing the percentage of migrated cells found on the underside of the Transwell membrane in the absence (control=100\%) or in the presence of opioids $\left(10^{-6} \mathrm{M}\right)$ after $24 \mathrm{~h}$. (D) Wound healing assay of T24 cells in the presence of DPDPE, DAMGO and U69,593 $\left(10^{-6} \mathrm{M}\right)$. Results are means \pm SEM of at least three independent experiments and "denotes statistical significance (p<0.05 at least). (E) Opioid receptor expression in different cancer cell lines. Opioid receptor expression $(\mu, \delta, \kappa)$ in different cell lines was assayed by RT-PCR as detailed in Materials and methods. PCR products were run on 2\% agarose gels and stained with ethidium bromide. G3PDH expression was used as a control for sample loading.

GGG AGT CCA GC-3', product 120 bp); $\delta$-Opioid Receptor (sense: 5'-ACC AAG ATC TGC GTG TTC CT-3' and antisense: 5'-CGA TGA CGA AGA TGT GGA TG-3' product 210 bp); $\mu$-Opioid Receptor (sense: 5'-CAT GCC ATT CCG ACC TTC-3' and antisense: 5'-AGG CAC TTT CCT AGA GAA TTA GAG C-3', product $100 \mathrm{bp}$ ); G3PDH (sense: 5'-TCC ACC ACC CTG TTG CTG TA-3' and antisense 5'-ACC ACA GTC CAT GCC ATC AC-3', product 449 bp). All primers were synthesized by MWG Biotech, Ebersberg, Germany. The products were run on $2 \%$ agarose gels and stained with ethidium bromide.

Assay of cell signaling proteins. Detection of signaling molecules was performed using a high-throughput Beadlyte Cell Signaling kit (Upstate, NY) and an xMAP Luminex 100 platform (Austin, TX). Cells were incubated with opioids for different time intervals, washed with ice-cold TBS and lysed using Universal lysis buffer or lysis buffer A, containing phosphatase inhibitors from the manufacturer and completed with complete protease inhibitors (Roche Diagnostics $\mathrm{GmbH}$, Mannheim, Germany) and sodium orthovanadate (SigmaHellas), according to the manufacturer's instructions. The following prosphorylated and total proteins were detected: total and phospho- (Ser473) Akt kinase, total and phospho(Thr185/Tyr187) ERK/MAP kinase $1 / 2$, total and phospho- (Thr180/Tyr182) p38 kinase, and total and phospho(Thr183/Tyr185) JNK kinase. Briefly, $25 \mu \mathrm{l}$ of each sample containing $25 \mu \mathrm{g}$ of protein were incubated overnight at $4^{\circ} \mathrm{C}$ in a 96-well plate with microsphere-coupled primary anti-bodies, washed and incubated with signaling molecules-specific reporter antibodies, followed by streptavidin-phycoerythrin according to the manufacturer's protocol and read using the 

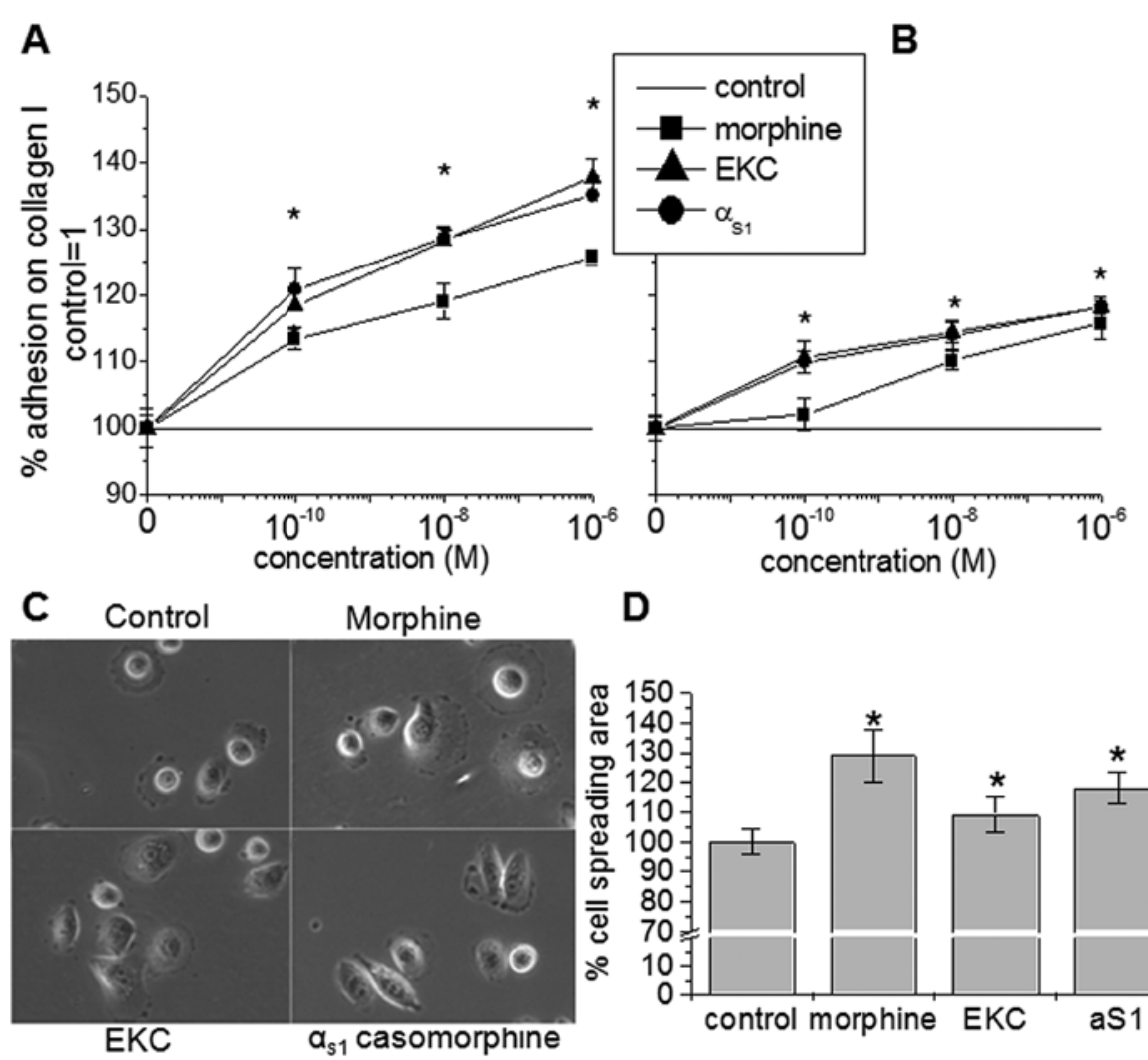

D
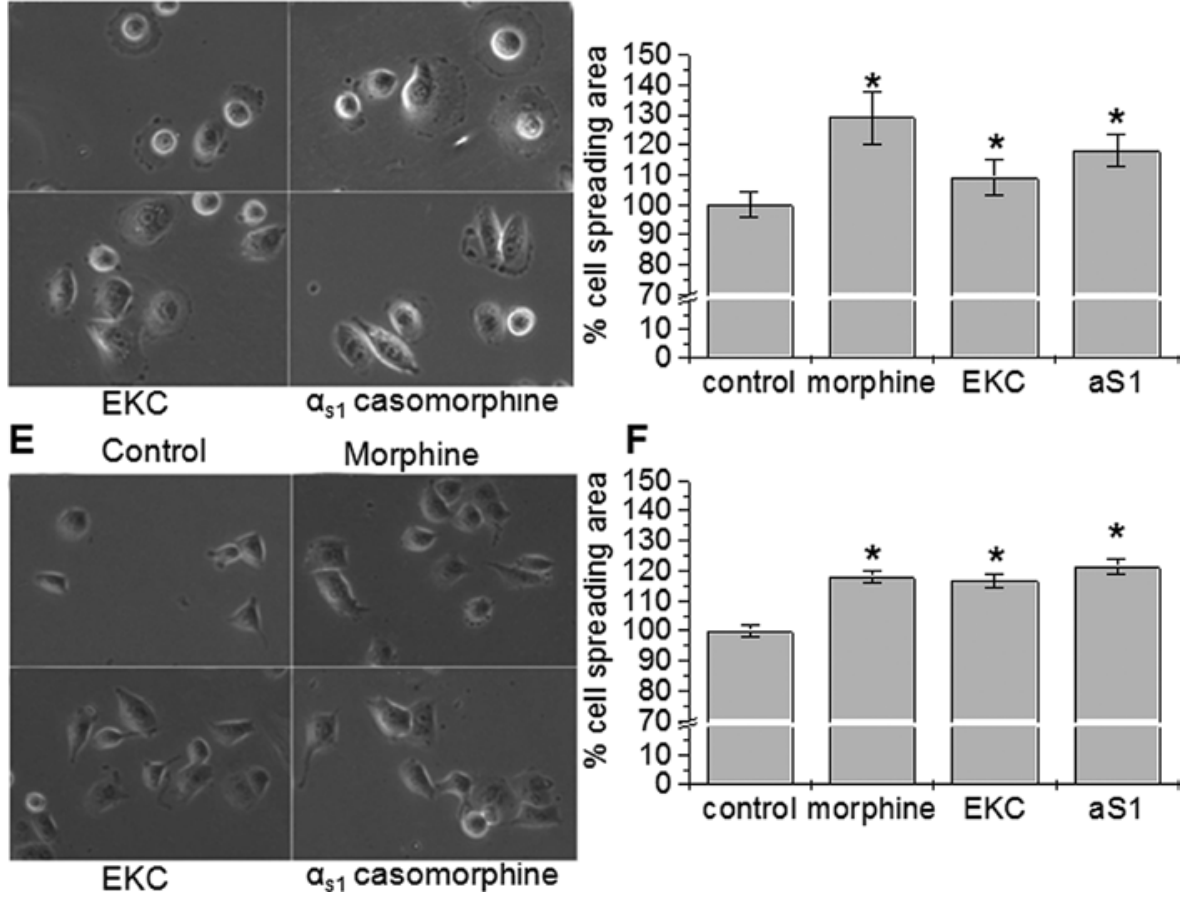

Figure 2. Effect of opioids on cell adhesion and spreading. (A and B) Adhesion of T24 (A) and EJ cells (B) on collagen I, pretreated (for 15 min) with different concentrations $\left(10^{-10}-10^{-6} \mathrm{M}\right)$ of morphine, EKC and $\alpha_{\mathrm{S} 1}$, after $1 \mathrm{~h}$ (T24) or $2 \mathrm{~h}$ (EJ). (C and E) Representative microphotographs of cell spreading on collagen I of T24 (C), and EJ cells (E) after $2 \mathrm{~h}$ of treatment with opioids. (D and F) Quantitation of cell spreading of T24 (D) and EJ cells (F), by multiple measurements of the area of $\sim 700$ cells per condition. Results are normalized to untreated cells (control=100\%) and *denotes statistical significance ( $<<0.05$ ).

Luminex 100. Total protein concentration was determined by the Bradford method using the Bio-Rad protein assay kit (Hercules, CA).

For Western blot analysis cells were cultured in six-well plates until $80 \%$ confluency. They were treated with morphine $\left(10^{-6} \mathrm{M}\right)$ for different time periods. Cells were washed three times with ice-cold PBS and lysed in $62.5 \mathrm{mM}$ Tris-HCl, pH 6.8, $10 \%$ glycerol, $2 \%$ SDS and freshly added phenylmethylsulfonyl fluoride $(10 \mathrm{mM})$ dithiothreitol, and $50 \mathrm{mM} \mathrm{Na} 2 \mathrm{~F}$. Cell lysates or the immunoprecipitates were suspended in Laemmli's sample buffer and separated by SDS-PAGE. Proteins were transferred onto nitrocellulose membrane, and the membrane was blocked with $5 \%$ non-fat dry milk in TBS-T (20 mM Tris, $\mathrm{pH} 7.6 ; 137 \mathrm{mM} \mathrm{NaCl} ; 0.05 \%$ Tween-20) for $2 \mathrm{~h}$ at room temperature. Antibody solutions (in TBS-T containing 3-5\% non-fat dry milk) were added overnight at $4^{\circ} \mathrm{C}$ (first antibody) and for $1 \mathrm{~h}$ (second horseradish peroxidase-coupled anti-rabbit antibody, dilution 1:4000). Blots were developed using the enhanced chemiluminescence system, and he band intensities were quantitated by PC-based image analysis (Image Analysis, Inc., Ontario, Canada). The following antibodies were used for the detection of phosphorylation of signaling proteins: ERK1/2, Biosource International, CA (Phospho ERK1/2, pTpY185/187, dilution 1:500, and total ERK1/2dilution 1: 500) and p38MAPK from Santa Cruz Biotechnology, CA (Phospho p38MAPK, c-20, sc535 dilution 1:300 and total p38MAPK dilution 1:300).

$B 2$ receptor silencing. Cells were treated with siRNA for $\mathrm{B} 2$ receptor (bradykinin B2R siRNA, Santa Cruz Biotechnology, CA, sc-29822) according to the manufacturer instructions. Briefly, cells were incubated with siRNA for $24 \mathrm{~h}$, siRNA containing medium was removed and $\mathrm{B} 2$ receptor expression was assayed by real-time PCR for bradykinin B2 receptor after 
T24
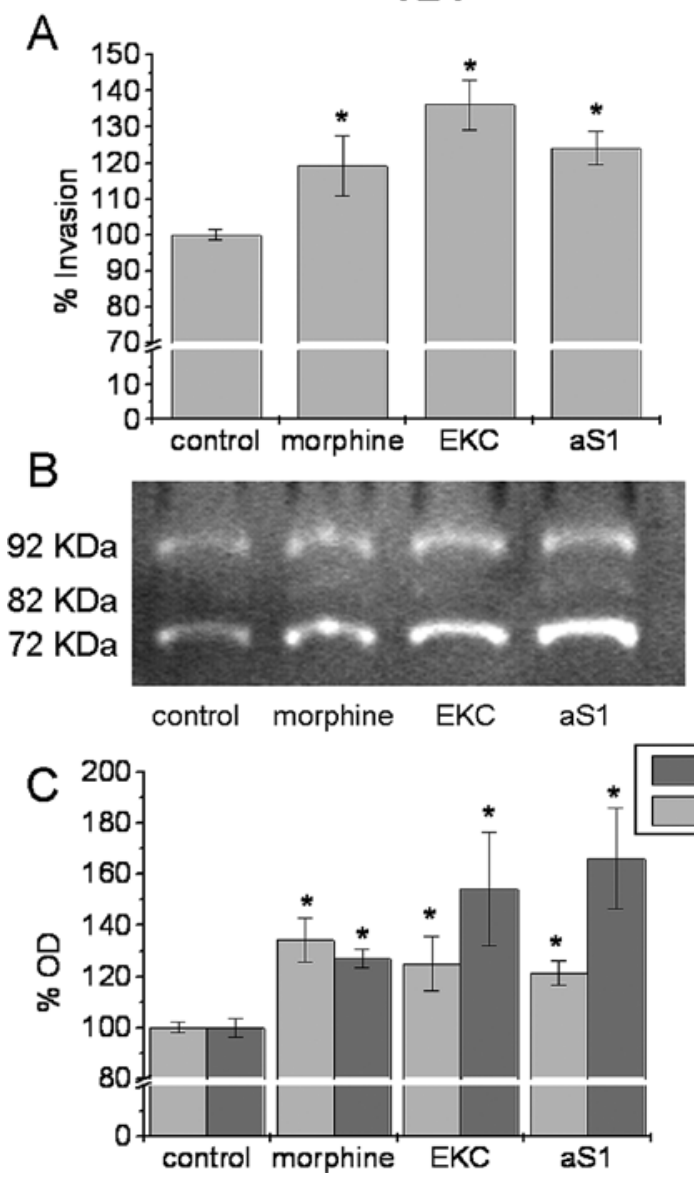

EJ
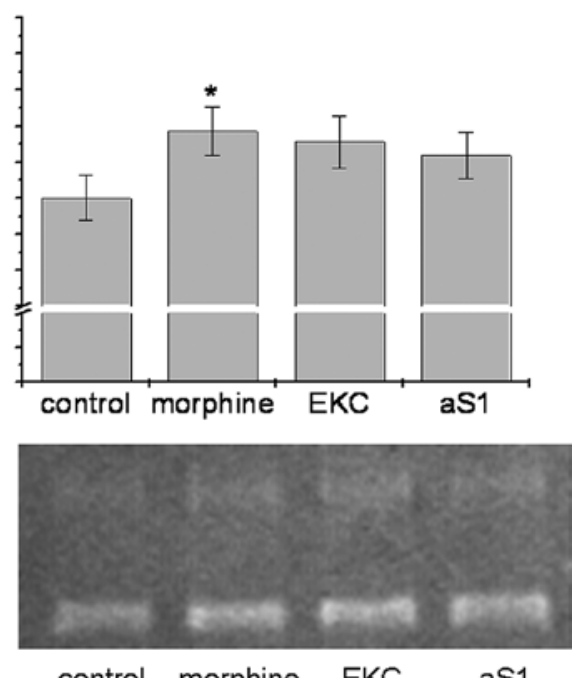

control morphine EKC aS1

\section{MMP-2}

MMP-9

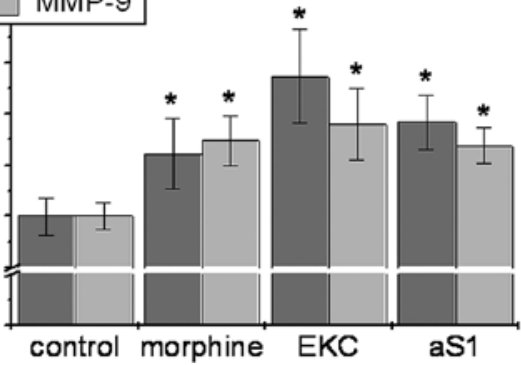

Figure 3. Invasion and MMP secretion of bladder carcinoma cells after opioid treatment. (A) Invasion of T24 (left column) and EJ cells (right column) through extracellular matrix-coated inserts in the absence (control) or in the presence of $10^{-6} \mathrm{M}$ morphine, EKC or $\alpha_{\mathrm{S} 1}$, after 24 h. Representative zymograph (pro-MMP-2 and pro-MMP-9) of T24 (left column) and EJ cells (right column) conditioned media after $24 \mathrm{~h}$ of opioid treatment (10-6 $\mathrm{M}$ morphine, EKC or $\alpha_{\mathrm{S} 1}$ casomorphine) (B) and quantitation of MMP-2 and MMP-9 secretion (C). Results are the mean \pm SEM of at least three independent experiments, performed in duplicates and *denotes statistical significance $(\mathrm{p}<0.05)$. Results are normalized per cell number, as described in Materials and methods.

24, 48 and $72 \mathrm{~h}$. A complete silence of expression was achieved after $72 \mathrm{~h}$. Afterwards, a scratch migration assay was performed in the absence or in the presence of morphine. A scrabled siRNA was used as a negative control.

Statistical analysis. Data are expressed as the means \pm SEM from the indicated number of experiments. All results are presented as a percentage compared to untreated cells (control=100\%). SEM for control was calculated by extrapolation the SEM of raw data. Significance of difference between untreated and treated cells with various reagents was determined by parametric methods, with the aid of the Origin V 5.0 (Microcal Software, Northampton, UK) and the Systat V 10.0 (SPSS, Chicago, IL) microcomputer programs. For couple comparisons, we have used Student's t-test. Statistical significance was set to $\mathrm{p}<0.05$.

\section{Results}

Opioids accelerate migration, adhesion and spreading of bladder cancer cells. When bladder cancer cells were incubated with a maximal concentration of different opioid agonists $\left(\mathrm{EKC}, \alpha_{\mathrm{S} 1}\right.$, morphine, $\left.10^{-6} \mathrm{M}\right)$, a significant increase of migration, adhesion and spreading was observed. Morphine, EKC and $\alpha_{\mathrm{S} 1}$ induced time-related wound coverage of T24 cells (Fig. 1A and B) while they accelerated cell transmigration by $16-43 \%$, after $24 \mathrm{~h}$ (Fig. 1C). However, this effect was substance-related, as DPDPE, DAMGO and U69,593 ( $\delta$-, $\mu$ and $\kappa$-opioid agonists respectively) exhibited a non-significant effect on migration (26\%, 5\% and $20 \%$ respectively) (Fig. 1D). Similar results were obtained with EJ cells (not shown).

Morphine, EKC and $\alpha_{\mathrm{S} 1}$ increased also T24 cell adhesion, in a dose-dependent manner, with $\mathrm{EC}_{50} \mathrm{~s}$ of $1.26 \times 10^{-11}$, $2.56 \times 10^{-12}$ and $1.46 \times 10^{-11} \mathrm{M}$, respectively (Fig. 2A). A similar, but less profound induction was also found in EJ cells, with $\mathrm{EC}_{50} \mathrm{~s}$ of $3.9 \times 10^{-9}, 1.61 \times 10^{-11}$ and $1.18 \times 10^{-11} \mathrm{M}$ for morphine, EKC and $\alpha_{\mathrm{S} 1}$ respectively (Fig. $2 \mathrm{~B}$ ).

Cell spreading was also affected by opioids $\left(2 \mathrm{~h}, 10^{-6} \mathrm{M}\right)$ : Morphine accelerated T24 cell spreading, increasing the average cell area by $29 \%$ (Fig. 2C and D), while EKC and $\alpha_{\mathrm{S} 1}$ induced a significant but less profound effect. Cell shape was also modified by opioids: while untreated cells were round, most treated cells were spindle-like shaped (Fig. 2C). A similar effect was also found in EJ cells (Fig. 2E-F). 


\section{A}

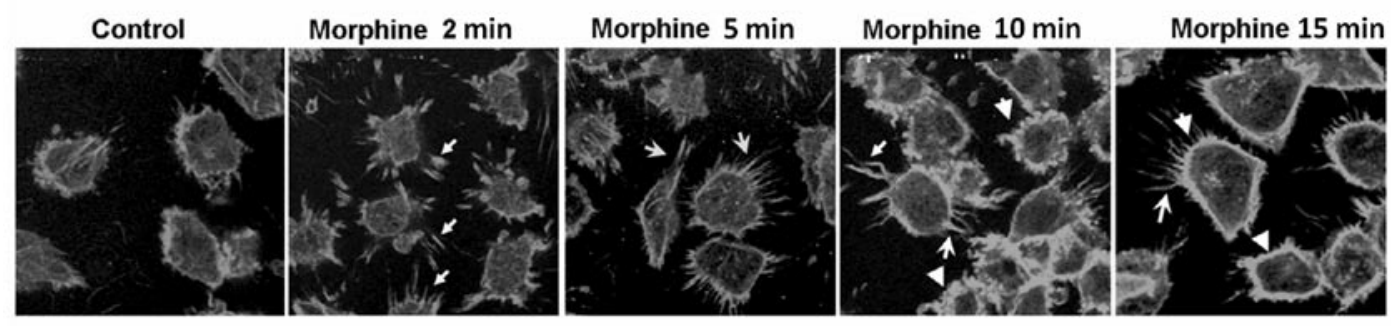

$\mathrm{B}$
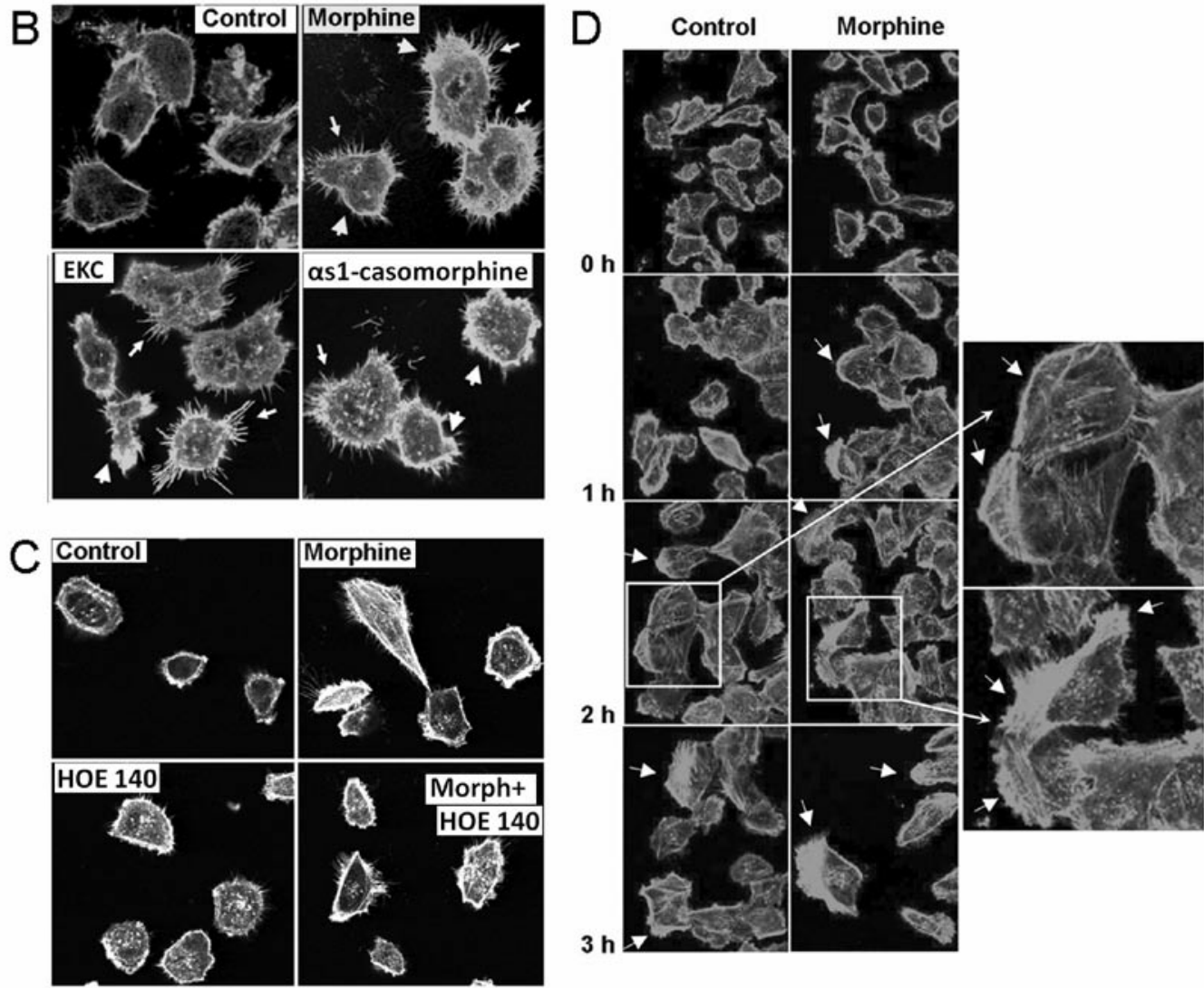

Figure 4. Effect of opioids on actin cytoskeleton. Confocal laser scanning micrographs of T24 cells stained with rhodamine-phalloidin. (A) Actin rearrangement after treatment with morphine $\left(10^{-6} \mathrm{M}\right)$ at different time-intervals $(0,2,5,10$ and $15 \mathrm{~min})$. (B) Actin cytoskeleton after treatment with $10^{-6} \mathrm{M}$ morphine, EKC and $\alpha_{\mathrm{s} 1}$, for $15 \mathrm{~min}$. (large arrows) lamellipodia, (arrows) filopodia and (arrow heads) cortical actin. (C) Actin cytoskeleton after treatment with $10^{-6} \mathrm{M}$ morphine, $10^{-5} \mathrm{M}$ HOE 140 and their combination, for $15 \mathrm{~min}$. (D) Formation of lamellipodia (arrows) during wound healing repair in the presence of $10^{-6} \mathrm{M}$ morphine for different time intervals $(0,1,2$ and $3 \mathrm{~h})$.

Opioids increase the invasive ability of T24 cells by increasing the secretion of matrix metalloproteinases. Opioids $\left(10^{-6} \mathrm{M}\right)$ were found to increase the invasiveness of T24 and EJ cells by $20-40 \%$ and $15-20 \%$ respectively (Fig. 3A), in a dose-dependent manner (not shown). ECM disruption and invasion largely depends on the secretion of matrix metalloproteinases (MMP). MMPs comprise a large family of matrix degrading enzymes (16), with MMP-2 and -9 being the most active isoforms (17-19). Indeed, pro-MMP-2 (72 kDa) and -9 (92 kDa) secretion in the culture medium paralleled the invasiveness of T24 and EJ cells (Fig. 3B and C). Additionally, opioids induced the secretion of active MMP-9 (82 kDa) by T24 cells (Fig. 3B). In EJ cells, in which opioid-induced invasiveness was lower, active MMP-9 was not found. However, in contrast to other cell systems, in which opioid-related MMP secretion is under NOS control (20), in bladder carcinoma cells, neither the NOS inhibitor L-NAME $(0.5 \mathrm{mM})$ nor the NO-donor SNAP $(0.05 \mathrm{mM})$ influenced their secretion, suggesting a NOS-independent pathway of opioid-related MMP secretion (not shown).

Opioids regulate actin cytoskeleton rearrangements. Adhesion and spreading are usually linked to rearrangements of actin cytoskeleton; in T24 cells, opioid $\left(10^{-6} \mathrm{M}\right)$ effects on actin cytoskeleton are time-related (morphine effect is shown in Fig. 4A, while the effect of EKC and $\alpha_{\mathrm{s} 1}$ at $15 \mathrm{~min}$ is presented in Fig. 4B). Opioid-treated cells displayed rapid (2-10 min) accumulation of cortical actin, formation of filamentous actin-containing complexes, accumulated most prominently within filopodia (Fig. 4A), extending from marginal edges of the cell and numerous microspikes. The ratio of cortical to total F-actin was $0.55 \pm 0.02$ in untreated cells, while morphine-, EKC- and $\alpha_{\mathrm{S1}}$-treated cells expressed a significantly increased ratio $(0.66 \pm 0.02,0.65 \pm 0.03$ and $0.59 \pm 0.03 ; \mathrm{p}<0.001)$. EJ cells (not presented) revealed similar changes. During 


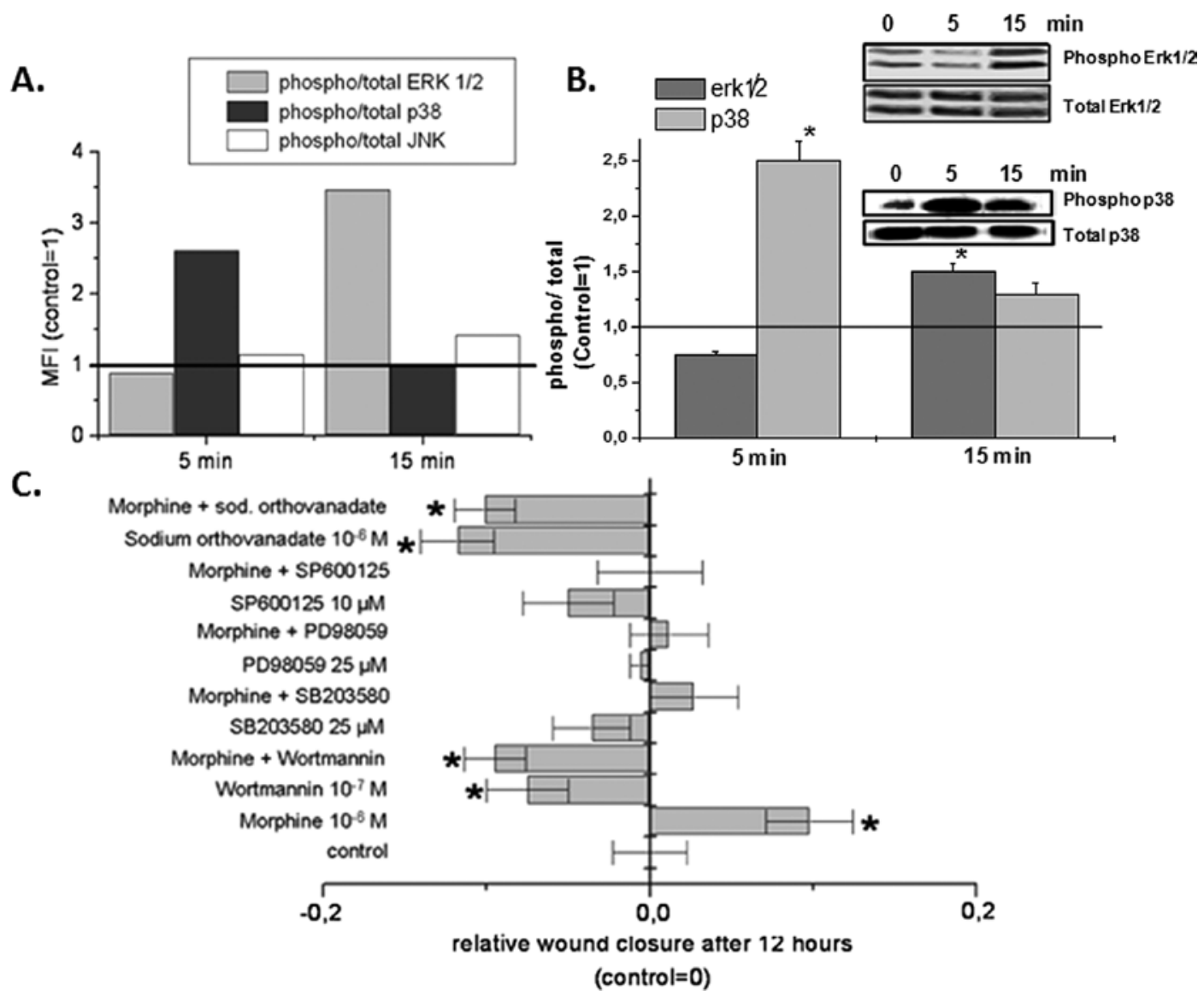

Figure 5. Signaling molecules implicated in the opioid effect (A) Phospho/total ratio of ERK 1/2 kinase, p38 kinase and JNK kinase after incubation of T24 cells with $10^{-6} \mathrm{M}$ morphine, for 5 and $15 \mathrm{~min}$. Results are presented as Median Fluorescence Intensity, (MFI, assayed by a multiplex bead assay, using specific antibodies), normalized to non-treated cells (control=1) and performed in duplicates, as described in Materials and methods. (B) Phospho/total ratio of ERK 1/2 kinase and p38MAPkinase after incubation of T24 cells with $10^{-6} \mathrm{M}$ morphine, for 5 and $15 \mathrm{~min}$ and assayed by Western blotting. Band intensity results are presented normalized to non-treated cells (control=1). Results are the means of at least three independent experiments and "denotes statistically significant results $(\mathrm{p}<0.05)$. (C) Inhibition of the action of morphine on cell migration, in the presence of wortmannin $\left(10^{-7} \mathrm{M}\right)$, SB203580 (25 $\left.\mu \mathrm{M}\right)$, PD98059 $(25 \mu \mathrm{M})$, SP600125 $(10 \mu \mathrm{M})$ and sodium orthovanadate $\left(10^{-6} \mathrm{M}\right)$.

migration and wound healing, morphine induced the marked formation of stress fibers and lamellipodia to the direction of movement (Fig. 4D). Lamellipodia formed in the presence of morphine and subcortical actin distribution were more intense, compared to untreated cells (cortical/total F-actin = $0.62 \pm 0.01$ for morphine-treated cells compared to $0.51 \pm 0.01$ for untreated cells, $\mathrm{p}<0.001)$.

Signaling pathways involved in migration induced by opioids. Morphine induced a rapid and transient p38 kinase phosphorylation (2.5-fold increase after $5 \mathrm{~min}$ and a return to basal levels after 10 more minutes) and a delayed (15 min) phosphorylation of ERK 1/2 (3.5-fold) and JNK (0.4-fold). No effect on the phosphorylation of Akt was observed (not shown), suggesting that this key signaling molecule might not be a downstream effector for the induction of migration and adhesion of bladder cancer cells (Fig. 5A). The results on the signaling molecules, identified by a multiplex-based assay, were verified with Western blotting of phosphorylated proteins, as presented in Fig. 5B. Incubation of cells with opioids in the presence of different signaling molecule inhibitors (Fig. 5C) resulted in a reversion of opioid migratory effect, confirming the implication of these signaling pathways in opioid-related migration. Inhibitors per se
Table I. Opioid and bradykinin B2 receptor expression in the different cancer cell lines tested in the present study.

\begin{tabular}{lcccc}
\hline & \multicolumn{3}{c}{ Opioid receptors } & \multicolumn{2}{c}{$\begin{array}{c}\text { Bradykinin B2 receptor } \\
\text { Binding }\end{array}$} \\
& \multicolumn{3}{c}{ (sites per cell)/PCR } & Binding \\
& $\mu$ & $\kappa$ & $\delta$ & \\
& (sites per cell)/PCR \\
T24 & $-/-$ & $-/-$ & $-/-$ & $1226 /+$ \\
EJ & $-/-$ & $-/-$ & $-/-$ & $700 /+$ \\
MCF7 & $1158 /+$ & $8340 /+$ & $1333 /+$ & $1179 /+$ \\
HepG2 & $-/-$ & $-/+$ & $-/-$ & $-/-$ \\
HeLa & $-/-$ & $-/-$ & $-/-$ & $-/-$ \\
SKOV-3 & $-/-$ & $-/-$ & $-/-$ & $-/-$ \\
\hline
\end{tabular}

Opioid sites were assayed by ligand binding assays and RT-PCR as detailed in Materials and methods.

did not significantly affect migration of T24 cells (with the exception of wortmannin which inhibited basal rate of T24 cell migration, suggesting the pivotal role of PI3K in cell migratory 
A
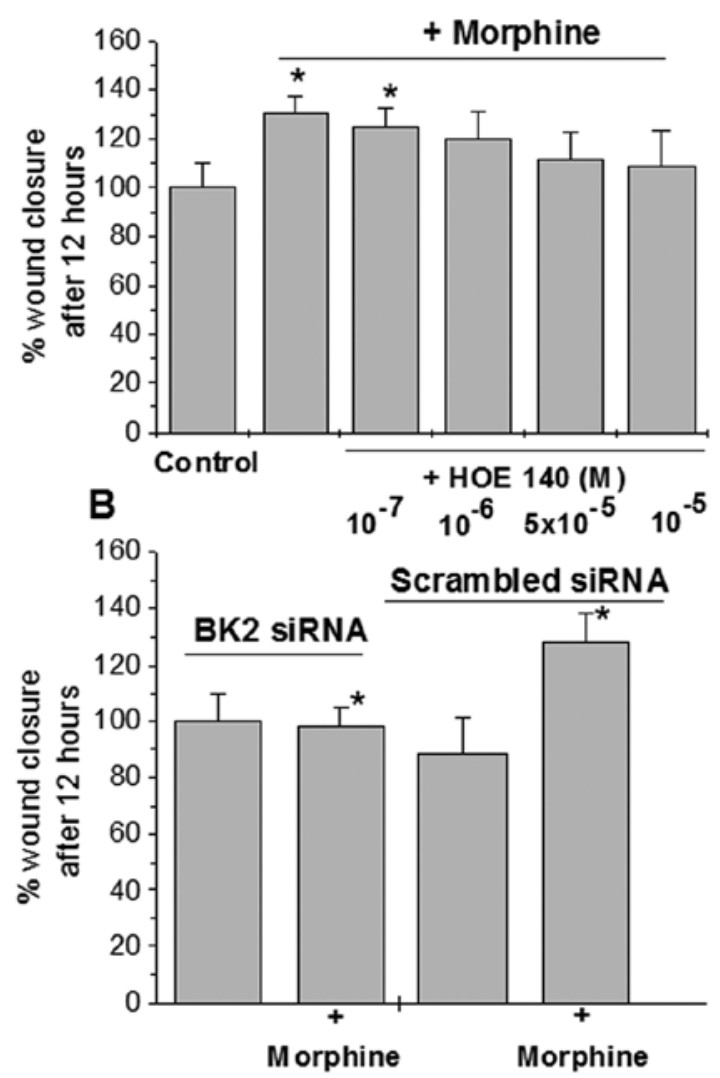

C
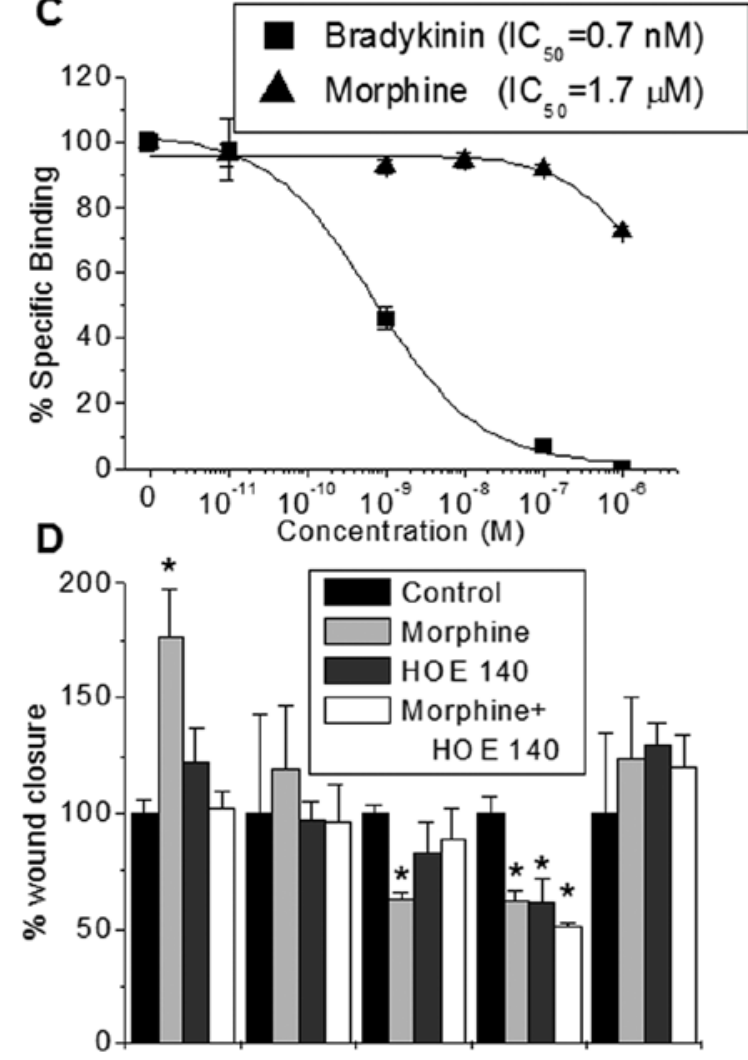

EJ MCF7 HepG2 Hela SKOV-3

Figure 6. Effect of the bradykinin receptor 2 antagonist HOE 140 and the B2 receptor siRNA on morphine-induced migration - $\left[{ }^{3} \mathrm{H}\right]$ bradykinin radioligand binding on T24 cells. (A) Repair of wounds in monolayers of T24 cells in the presence of morphine and the B2 receptor antagonist $\mathrm{HOE}^{140}$ (10 $\left.{ }^{-7}-10^{-5} \mathrm{M}\right)$, after $12 \mathrm{~h}$ of incubation. Wound healing of control (untreated) cells is considered $100 \%$. (B) [ $\left.{ }^{3} \mathrm{H}\right] \mathrm{Bradykinin}$ displacement on T24 cells by unlabelled bradykinin and by morphine. Repair of wounds in monolayers of T24 cells transiently transfected with the B2 receptor siRNA in the presence or absence of morphine $\left(10^{-6} \mathrm{M}\right)$, after $12 \mathrm{~h}$ of incubation. Scrambled siRNA was used as a negative control. Wound healing of T24 cells transfected with the B2 receptor siRNA is considered $100 \%$. (C) [ $\left.{ }^{3} \mathrm{H}\right]$ Bradykinin displacement on T24 cells by unlabelled bradykinin and by morphine. (D) Repair of wounds in monolayers of EJ, MCF7, HepG2, HeLa and SKOV-3 cells in the presence of morphine and the B2 receptor antagonist HOE 140 (10 ${ }^{-5}$ M). EJ and SKOV-3 cells were examined after $12 \mathrm{~h}$ of incubation while MCF7 and HeLa cells were examined after $24 \mathrm{~h}$ and HepG 2 cells after 3 days of incubation. Results are means of at least three independent experiments and *denotes statistically significant results $(\mathrm{p}<0.05)$.

activity but in a manner not implicating opioids). The involvement of the above signaling molecules was further confirmed by the use of the general protein tyrosine phosphatase inhibitor sodium orthovanadate $\left(10^{-6} \mathrm{M}\right)$. As shown, inhibition of the action of phosphatases reverts the effect of opioids on migration.

The enhanced effect of opioids on T24 and EJ cell migration involves bradykinin receptors. The results presented above indicate that opioids increase migration, invasion and spreading of bladder cancer cells, rearranging the actin cytoskeleton and inducing the phosphorylation of key signaling molecules. However, ligand binding assays (assaying the active receptor protein) and RT-PCR, assaying the mRNA transcript (Table I, Fig. 1E) revealed that bladder cancer cells do not express opioid receptors, while opioid antagonists (naloxone and diprenorphine) failed to inhibit the action of morphine (not shown). Therefore, the effect of opioids on bladder cancer cell migration is independent of the presence of opioid receptors and should be mediated through their interaction with other membrane-related molecules.

A number of membrane receptors, are involved in the migratory activity and enhanced invasion of cancer cells, inducing signaling molecule changes as those presented here: hepatocyte growth factor receptor (c-met) (21), CXCR4 chemokine receptor (22), bradykinin (BK) B2 receptor $(23,24)$, urokinase plasminogen activator receptor (uPAR) (25) and vascular endothelial growth factor receptor (VEGF) $(26,27)$. In order to point out the most probable candidate we examined the effect of opioids on migration of a number of cell lines, reported to express these receptors: MCF7 breast cancer, HepG2 hepatocellular carcinoma, HeLa cervix carcinoma, that express c-met, uPAR (28-35) and VEGF receptors $(36,37)$, and CXCR4 (38-40) and SKOV-3 ovarian carcinoma cells, expressing only c-met and UPAR (27). MCF7 was the only cell line expressing functional opioid receptors (Table I). Morphine inhibited hepatocellular (HepG2) and cervical carcinoma cell (HeLa) migration (14\% and $15 \%$ respectively), did not affect breast (MCF7) and ovarian carcinoma cells (SKOV-3), while it decreased the adhesion of HeLa cells by $16 \%$. Additionally, no significant effect was observed on the spreading of MCF7, HepG2 and SKOV-3 cells indicating that the enhancement of the migratory activity by opioids is characteristic of the bladder cancer cells (Table II; other opioids had a similar action on the assayed parameters, not presented). As these cell lines (with the 
Table II. Migration (wound healing), transmigration, adhesion and spreading of cancer cells of different origin (bladder-T24 and EJ, breast-MCF7, liver-HepG2, ovary-SKOV-3 and cervix-HeLa) in the presence of morphine $\left(10^{-6} \mathrm{M}\right)$.

\begin{tabular}{|c|c|c|c|c|c|c|c|c|}
\hline & \multicolumn{2}{|c|}{ Migration (wound healing) ${ }^{\mathrm{a}}$} & \multicolumn{2}{|c|}{ Transmigration $^{\mathrm{b}}$} & \multicolumn{2}{|c|}{ Adhesion $^{\mathrm{c}}$} & \multicolumn{2}{|c|}{ Spreading $^{\mathrm{c}}$} \\
\hline & Control & Morphine & Control & Morphine & Control & Morphine & Control & Morphine \\
\hline $\mathrm{T} 24$ & $35.3 \pm 6.2$ & $52.9 \pm 4.5^{\mathrm{d}}$ & $100 \pm 3.9$ & $127 \pm 2.9^{\mathrm{d}}$ & $100 \pm 1.3$ & $126 \pm 1.3^{\mathrm{d}}$ & $100 \pm 1.9$ & $128 \pm 5.4^{\mathrm{d}}$ \\
\hline EJ & $19.8 \pm 1.7$ & $28.1 \pm 6.2^{\mathrm{d}}$ & $100 \pm 2.2$ & $118 \pm 3.3^{\mathrm{d}}$ & $100 \pm 1.7$ & $116 \pm 2.5^{\mathrm{d}}$ & $100 \pm 2.0$ & $118 \pm 1.9^{\mathrm{d}}$ \\
\hline MCF7 & $30.7 \pm 13$ & $36.7 \pm 10$ & $100 \pm 5.2$ & $111 \pm 5.5$ & $100 \pm 1.2$ & $93 \pm 1.5$ & $100 \pm 1.4$ & $99 \pm 1.3$ \\
\hline HepG2 & $28.3 \pm 2.5$ & $17.8 \pm 2.5^{\mathrm{d}}$ & $100 \pm 3.2$ & $83.3 \pm 4.1^{\mathrm{d}}$ & $100 \pm 2.3$ & $94 \pm 1.7$ & $100 \pm 4.0$ & $100 \pm 4.8$ \\
\hline SKOV-3 & $13.1 \pm 4.5$ & $16.2 \pm 4.4$ & $100 \pm 3.6$ & $95 \pm 4.5$ & $100 \pm 1.1$ & $102 \pm 2.7$ & $100 \pm 5.8$ & $96 \pm 6.7$ \\
\hline $\mathrm{HeLa}$ & $28.2 \pm 2.2$ & $17.5 \pm 1.2^{\mathrm{d}}$ & $100 \pm 4.2$ & $86 \pm 3.4^{\mathrm{d}}$ & $100 \pm 4.2$ & $84 \pm 5.6^{\mathrm{d}}$ & $100 \pm 3.2$ & $102 \pm 3.1$ \\
\hline
\end{tabular}

${ }^{\mathrm{a}} \mathrm{T} 24, \mathrm{EJ}$ and SKOV-3 cells were examined after $12 \mathrm{~h}, \mathrm{MCF} 7$ and HeLa cells after $24 \mathrm{~h}$ and HepG2 cells after 3 days. Results are presented as $\%$ wound closure of the total wound area at $0 \mathrm{~h}$. ${ }^{\mathrm{b}}$ Transmigration experiments were assayed after $24 \mathrm{~h}$ for all cells. ${ }^{\mathrm{c}} \mathrm{Adhesion}$ and spreading were assayed after $2 \mathrm{~h}$ for all cells. ${ }^{\mathrm{b}}$ and $\mathrm{R}$ Results are normalized to control $(=100 \%) \pm$ SEM of at least three independent experiments performed in triplicate; ${ }^{\mathrm{d}}$ denotes statistically significant differences compared to control, as evaluated with t-test.

exception of MCF7 cells) do not bear functional opioid receptors (Table I), and the effect of opioids was different from that found in bladder cells, we have ruled out the implication of c-met, UPAR, VEGF and CXCR4 receptors on migration, adhesion, invasion and spreading of T24 and EJ cells. It derives that a potential candidate explaining our data is the BK B2 receptor. BK $\mathrm{B} 2$ receptor is expressed by $\mathrm{T} 24$ and MCF7 cells (23) and it has been previously found to interact with opioids $(41,42)$ as well as to induce bladder cancer motility (24).

T24 and EJ cells bear functional BK B2 receptors (1226 and 700 sites/cell respectively) with a $\mathrm{K}_{\mathrm{D}}$ of $0.7 \mathrm{nM}$ (Fig. 6C). Morphine was a weak competitor of bradykinin binding, interacting with an almost 1000-times lower affinity. Additionally, incubation of T24 cells with morphine $\left(10^{-6} \mathrm{M}\right)$ and the specific bradykinin B2 receptor antagonist HOE $140\left(10^{-7}-10^{-5} \mathrm{M}\right)$ inhibited migration in a dose-dependent manner (Fig. 6A). Moreover, changes on actin cytoskeleton induced by morphine in T24 cells were partly reversed by HOE $140\left(10^{-5} \mathrm{M}\right)$ (Fig. 4C). Similarly, the effect of morphine on the ratio of cortical/total F-actin was affected in the presence of HOE $140(0.51 \pm 0.03$, $0.62 \pm 0.02,0.44 \pm 0.03$ and $0.55 \pm 0.03$ for control, morphine, HOE 140 and morphine+HOE 140, respectively).

The specificity of $\mathrm{B} 2$ receptor involvement in cell migration was confirmed by incubating the different cell lines with opioids (morphine, $10^{-6} \mathrm{M}$ ), in the presence of the BK B2 antagonist HOE $140\left(10^{-5} \mathrm{M}\right)$. As presented in Fig. 6D, in EJ cells, the migratory effect of morphine was reverted by the addition of HOE 140, suggesting the implication of BK B2 receptors. In contrast, the effect of morphine was not modified in the other cell lines, with the exception of HepG2. However, taking into consideration the absence of $\mathrm{BK} \mathrm{B} 2$ and opioid receptors (Table I) this could be due to an interaction of opioids and BK antagonists with another unidentified membrane receptor system.

Finally, the effect of morphine was also studied in T24 cells that were transiently transfected with specific siRNA for B2 receptor. Seventy-two hours after transfection B2 receptor expression was completely silenced, as assayed by real-time PCR (data not shown). When these cells were used for the migration assay, morphine-induced T24 cell migration (Fig. 6B) was inhibited, indicating a B2 receptor mediated effect.

\section{Discussion}

Bladder cancer is the fourth most common cancer and the ninth leading cause of cancer death $(43,44)$. Most of the cases are transitional cell carcinoma (TCC) and 20-30\% of them express the lethal non-papillary invasive TCC phenotype, with lymphatic and distant metastasis. The bladder concentrates the excreted amounts of administered opioids and their metabolites, while endogenous opioid peptides are produced within the urogenital tract $(45,46)$. Furthermore, $\sim 45 \%$ of bladder tumor-infiltrating lymphocytes consist of T-cells (47), able to secrete endogenous opioids (48-50), that can affect tumor progression. However, the effect of opioids on cell migration, adhesion, spreading and invasion in solid organs is much less studied than their action on cell proliferation and apoptosis. In fact, conflicting results have been reported, with opioids decreasing $(5,6,51)$, increasing $(7,8,52)$, or having no effect on cell motility (9). Our data extend and confirm these observations: depending on the cell line, opioids were found to exert no effect (MCF7 and SKOV-3 cells), decrease (HepG2 and HeLa cells) or increase (T24 and EJ), migration, adhesion, spreading and invasion.

Cell spreading, migration and invasion of solid organs includes disruption of the extracellular matrix, under the action of proteases, especially MMPs (53-55), which are also been involved in early steps of tumor evolution, proliferation and angiogenesis (56). The results of the present, as well as previous study (20), indicate that opioids might efficiently modify MMP secretion, depending on the cell type and the mechanism involved. Indeed, previous data indicate that opioids decrease MMP secretion by mouse fibrosarcoma cells, through the $\mathrm{NO} /$ NOS system (20), while our findings indicate that in human bladder cancer cells, they increase MMP secretion in a $\mathrm{NO} /$ NOS-independent mechanism.

Our results further suggest that opioids promote motility and invasiveness of bladder cancer cells, in a non-opioid receptor-mediated manner, through rapid modification of 
signaling molecules (p38 MAPK, JNK and ERK 1/2 kinases) and actin cytoskeleton redistribution. Reported data indicate an interplay of opioids with an increasing number of alternative membrane receptor systems in addition to opioid receptors: such as somatostatin (reviewed in ref. 57), adrenergic (58), chemokine $(59,60)$, or bradykinin receptors $(41,42)$. Furthermore, there are scarce data indicating an internalization of opioid peptides, which can interact subsequently with signaling pathways (61). Our data provide a mechanistic framework for the interaction of opioids with bradykinin B2 receptors in bladder cancer cells: i) B2 receptors are expressed in T24 cells and to a lesser extent in EJ cells, ii) B2 receptor activation is able to induce the observed changes in signaling molecules (62; reviewed in ref. 63), iii) co-incubation of bladder cancer cells with the specific B2 receptor antagonist HOE 140, or silencing it with siRNA, reverses the action of opioids in T24 and EJ cells, iv) opioids have an inhibitory or no effect on cancer cells of different origin that do not express the $\mathrm{B} 2$ receptor or the opioid receptors and v) in this latter case (MCF7 cells), their action is mediated via opioid receptors, since co-incubation of the cells with HOE 140 does not revert opioid action. Furthermore, bradykinin has been previously found to induce the migratory activity of bladder cancer cells (24), a result which is partially mimicked by opioids. Similar interaction of opioids, with bradykinin receptors has been recently reported. More specifically, dynorphin A was found to activate bradykinin receptors and maintain neuropathic pain $(41,42)$. The affinity of dynorphin A for the bradykinin B2 receptor $(1.4-2 \mu \mathrm{M})$ is comparable to the affinity we have found for morphine $(1.7 \mu \mathrm{M})$. However, the physiological significance of this finding needs further study, as all opioids interact on B2 receptor with a 1000 -fold lower affinity than the cognitive ligand. An alternative possibility, which equally needs further investigation, might be that the effect of morphine in activating B2 receptors is indirect perhaps through an autocrine action by activating the production of bradykinin.

Our data demonstrate that opioid-induced enhancement of migration, adhesion, spreading and invasion is a bladder cancer cell-defined phenomenon that is mediated through an interaction of opioids with the bradykinin B2 receptor. This effect suggests a pluripotency of opioid-other membrane receptor interactions, in the absence of cognitive receptors. In view of these findings, using opioids in cancer patients, in spite of their unique role in pain relief, one should keep in mind that they may also exert beneficial (protection) or adverse effects (spreading of cancer cells).

\section{References}

1. Wu W, Yamaura T, Murakami K, et al: Social isolation stress enhanced liver metastasis of murine colon 26-L5 carcinoma cells by suppressing immune responses in mice. Life Sci 66: 1827-1838, 2000.

2. Zoller M, Heumann U, Betzler M, Stimmel H and Matzku S: Depression of nonadaptive immunity after surgical stress: influence on metastatic spread. Invasion Metastasis 9: 46-68, 1989.

3. Sawynok J: Topical and peripherally acting analgesics. Pharmacol Rev 55: 1-20, 2003.

4. Stein C, Schafer M and Machelska H: Attacking pain at its source: new perspectives on opioids. Nat Med 9: 1003-1008, 2003.

5. Harimaya Y, Koizumi K, Andoh T, Nojima H, Kuraishi Y and Saiki I: Potential ability of morphine to inhibit the adhesion, invasion and metastasis of metastatic colon 26-L5 carcinoma cells. Cancer Lett 187: 121-127, 2002.
6. Weeks BS, Goldman S, Touma S, Payne M, Cadet P and Stefano GB: Morphine inhibits indolactam V-induced U937 cell adhesion and gelatinase secretion. J Cell Physiol 189: 179-188, 2001.

7. Drell TL, Joseph J, Lang K, Niggemann B, Zaenker KS and Entschladen F: Effects of neurotransmitters on the chemokinesis and chemotaxis of MDA-MB-468 human breast carcinoma cells. Breast Cancer Res Treat 80: 63-70, 2003.

8. Ruff M, Schiffmann E, Terranova V and Pert CB: Neuropeptides are chemoattractants for human tumor cells and monocytes: a possible mechanism for metastasis. Clin Immunol Immunopathol 37: 387-396, 1985.

9. Zagon IS, Rahn KA and McLaughlin PJ: Opioids and migration, chemotaxis, invasion, and adhesion of human cancer cells. Neuropeptides 41: 441-452, 2007.

10. Patel J, Manjappa N, Bhat R, Mehrotra P, Bhaskaran M and Singhal PC: Role of oxidative stress and heme oxygenase activity in morphine-induced glomerular epithelial cell growth. Am J Physiol Renal Physiol 285: F861-F869, 2003.

11. Hatzoglou A, Bakogeorgou E, Papakonstanti E, Stournaras C, Emmanouel DS and Castanas E: Identification and characterization of opioid and somatostatin binding sites in the opossum kidney (OK) cell line and their effect on growth. J Cell Biochem 63: 410-421, 1996

12. Kampa M, Loukas S, Hatzoglou A, Martin P, Martin PM and Castanas E: Identification of a novel opioid peptide (Tyr-ValPro-Phe-Pro) derived from human alpha S1 casein (alpha S1-casomorphin, and alpha S1-casomorphin amide). Biochem J 319: 903-908, 1996.

13. Mosmann T: Rapid colorimetric assay for cellular growth and survival: application to proliferation and cytotoxicity assays. J Immunol Methods 65: 55-63, 1983.

14. Kueng W, Silber E and Eppenberger U: Quantification of cells cultured on 96-well plates. Anal Biochem 182: 16-19, 1989.

15. Kleiner DE and Stetler-Stevenson WG: Quantitative zymography: detection of picogram quantities of gelatinases. Anal Biochem 218: 325-329, 1994.

16. Curran S and Murray GI: Matrix metalloproteinases: molecular aspects of their roles in tumour invasion and metastasis. Eur $\mathrm{J}$ Cancer 36: 1621-1630, 2000.

17. Tokar EJ and Webber MM: Cholecalciferol (vitamin D3) inhibits growth and invasion by up-regulating nuclear receptors and 25-hydroxylase (CYP27A1) in human prostate cancer cells. Clin Exp Metastasis 22: 275-284, 2005.

18. Shellman YG, Makela M and Norris DA: Induction of secreted matrix metalloproteinase-9 activity in human melanoma cells by extracellular matrix proteins and cytokines. Melanoma Res 16: 207-211, 2006.

19. Hagemann T, Robinson SC, Schulz M, Trumper L, Balkwill FR and Binder C: Enhanced invasiveness of breast cancer cell lines upon co-cultivation with macrophages is due to TNF-alpha dependent up-regulation of matrix metalloproteases. Carcinogenesis 25: 1543-1549, 2004.

20. Shariftabrizi A, Nifli AP, Ansari M, et al: Matrix metalloproteinase 2 secretion in WEHI 164 fibrosarcoma cells is nitric oxide-related and modified by morphine. Eur J Pharmacol 530: 33-39, 2006.

21. Wang P, Nishitani MA, Tanimoto S, et al: Bladder cancer cell invasion is enhanced by cross-talk with fibroblasts through hepatocyte growth factor. Urology 69: 780-784, 2007.

22. Retz MM, Sidhu SS, Blaveri E, et al: CXCR4 expression reflects tumor progression and regulates motility of bladder cancer cells. Int J Cancer 114: 182-189, 2005.

23. Lung CC, Jagels MA, Daffern PJ, Tan EM and Zuraw BL: Induction of human $\mathrm{B} 2$ bradykinin receptor $\mathrm{mRNA}$ and membrane receptors by IFNgamma. Immunopharmacology 39: 243-253, 1998.

24. Baba K and Yamaguchi O: Effects of bradykinin on cytoplasmic calcium and motility in murine bladder tumor cells. J Urol 165: 259-262, 2001.

25. Hudson MA and McReynold LM: Urokinase (u-PA) and the u-PA receptor. Modulation of in vitro invasiveness of human bladder cancer cell lines. Adv Exp Med Biol 462: 399-412, 1999.

26. Wu W, Shu X, Hovsepyan H, Mosteller RD and Broek D: VEGF receptor expression and signaling in human bladder tumors. Oncogene 22: 3361-3370, 2003.

27. Shi X, Chen G, Xing H, Weng D, Bai X and Ma D: VEGF-C, VEGFR-3, and COX-2 enhances growth and metastasis of human cervical carcinoma cell lines in vitro. Oncol Rep 18: 241-247, 2007. 
28. Parr C and Jiang WG: Expression of hepatocyte growth factor/ scatter factor, its activator, inhibitors and the c-Met receptor in human cancer cells. Int J Oncol 19: 857-863, 2001.

29. Stillfried GE, Saunders DN and Ranson M: Plasminogen binding and activation at the breast cancer cell surface: the integral role of urokinase activity. Breast Cancer Res 9: R14, 2007.

30. Xie Q, Liu KD, Hu MY and Zhou K: SF/HGF-c-Met autocrine and paracrine promote metastasis of hepatocellular carcinoma. World J Gastroenterol 7: 816-820, 2001

31. Monvoisin A, Neaud V, De Ledinghen V, et al: Direct evidence that hepatocyte growth factor-induced invasion of hepatocellular carcinoma cells is mediated by urokinase. J Hepatol 30: 511-518, 1999.

32. Kermorgant S, Zicha D and Parker PJ: PKC controls HGFdependent c-Met traffic, signalling and cell migration. EMBO J 23: 3721-3734, 2004.

33. Ertongur S, Lang S, Mack B, Wosikowski K, Muehlenweg B and Gires O: Inhibition of the invasion capacity of carcinoma cells by WX-UK1, a novel synthetic inhibitor of the urokinase-type plasminogen activator system. Int J Cancer 110: 815-824, 2004.

34. Herter S, Piper DE, Aaron W, et al: Hepatocyte growth factor is a preferred in vitro substrate for human hepsin, a membraneanchored serine protease implicated in prostate and ovarian cancers. Biochem J 390: 125-136, 2005.

35. Whitley BR, Beaulieu LM, Carter JC and Church FC: Phosphatidylinositol 3-kinase/Akt regulates the balance between plasminogen activator inhibitor-1 and urokinase to promote migration of SKOV-3 ovarian cancer cells. Gynecol Oncol 104 470-479, 2007

36. Wu Y, Hooper AT, Zhong Z, et al: The vascular endothelial growth factor receptor (VEGFR-1) supports growth and survival of human breast carcinoma. Int J Cancer 119: 1519-1529, 2006.

37. Baek JH, Jang JE, Kang CM, Chung HY, Kim ND and Kim KW: Hypoxia-induced VEGF enhances tumor survivability via suppression of serum deprivation-induced apoptosis. Oncogene 19: 4621-4631, 2000.

38. El Messaoudi K, Thiry LF, Liesnard C, Van Tieghem N, Bollen A and Moguilevsky N: A human milk factor susceptible to cathepsin D inhibitors enhances human immunodeficiency virus type 1 infectivity and allows virus entry into a mammary epithelial cell line. J Virol 74: 1004-1007, 2000.

39. Mitra P, De A, Ethier MF, et al: Loss of chemokine SDF-1alphamediated CXCR4 signalling and receptor internalization in human hepatoma cell line HepG2. Cell Signal 13: 311-319, 2001.

40. Peng SB, Peek V, Zhai Y, et al: Akt activation, but not extracellular signal-regulated kinase activation, is required for SDF-1alpha/CXCR4-mediated migration of epitheloid carcinoma cells. Mol Cancer Res 3: 227-236, 2005.

41. Altier $\mathrm{C}$ and Zamponi GW: Opioid, cheating on its receptors, exacerbates pain. Nat Neurosci 9: 1465-1467, 2006.

42. Lai J, Luo MC, Chen Q, et al: Dynorphin A activates bradykinin receptors to maintain neuropathic pain. Nat Neurosci 9: 1534-1540, 2006.

43. Gloeckler Ries LA, Reichman ME, Lewis DR, Hankey BF and Edwards BK: Cancer survival and incidence from the Surveillance, Epidemiology, and End Results (SEER) program. Oncologist 8: 541-552, 2003.

44. Jemal A, Siegel R, Ward E, Murray T, Xu J and Thun MJ: Cancer statistics, 2007. CA Cancer J Clin 57: 43-66, 2007.

45. Krieger DT, Margioris AN, Liotta AS, Shaha C, Gerandai I, Pintar J and Bardin CW: Pro-Opiomelanocortin-derived peptides in the rodent male reproductive tract. In: Opioid Modulation of Endocrine Function. G. Delitala MM and M. Serio (eds.). Raven Press, New York, pp223-235, 1984.
46. Tainio H: Peptidergic innervation of the human prostate, seminal vesicle and vas deferens. Acta Histochem 97: 113-119, 1995.

47. Tsujihashi H, Matsuda H, Uejima S, Akiyama T and Kurita T: Immunocompetence of tissue infiltrating lymphocytes in bladder tumors. J Urol 140: 890-894, 1988.

48. Cabot PJ: Immune-derived opioids and peripheral antinociception. Clin Exp Pharmacol Physiol 28: 230-232, 2001.

49. Maestroni GJ and Conti A: Immuno-derived opioids as mediators of the immuno-enhancing and anti-stress action of melatonin. Acta Neurol (Napoli) 13: 356-360, 1991.

50. Yahata T, Yahata C, Ohta A, et al: Interleukin-4-dependent induction of preproenkephalin in antigen-specific $\mathrm{T}$ helper-type 2 (Th2) cells. J Neuroimmunol 105: 103-108, 2000.

51. Martin JL, Koodie L, Krishnan AG, Charboneau R, Barke RA and Roy S: Chronic morphine administration delays wound healing by inhibiting immune cell recruitment to the wound site. Am J Pathol 176: 786-799, 2010.

52. Debruyne D, Leroy A, De Wever O, Vakaet L, Mareel M and Bracke M: Direct effects of delta opioid receptor agonists on invasion-associated activities of HCT-8/E11 colon cancer cells. Anticancer Res 30: 9-17, 2010.

53. Brown P, Bloxidge R, Stuart N, Gatter K and Carmichael J: Association between expression of activated 72-kilodalton gelatinase and tumor spread in non-small-cell lung carcinoma. J Natl Cancer Inst 85: 574-578, 1993.

54. Davies B, Miles D, Happerfield L, et al: Activity of type IV collagenase in benign and malignant breast disease. Br J Cancer 72: 575-582, 1993

55. Emmert-Buck M, Roth M, Zhuang Z, et al: Invasive gelatinase $\mathrm{A}(\mathrm{MMP}-2)$ and cathepsin B activity in invasive tumor regions of human colon cancer samples. Am J Pathol. 145: 1285-1290, 1994.

56. Stetler-Stevenson W: Type IV collagenases in tumor invasion and metastasis. Cancer Metastasis Rev 9: 289-303, 1990.

57. Hatzoglou A, Kampa M and Castanas E: Opioid-somatostatin interactions in regulating cancer cell growth. Front Biosci 10 244-256, 2005.

58. Wu WR, Zheng JW, Li FY, Li Y, Zhang KR and Bai HQ: Involvement of mu-opioid receptors and alpha-adrenoceptors in the immunomodulatory effects of dihydroetorphine. Eur J Pharmacol 353: 79-85, 1998.

59. Patel JP, Sengupta R, Bardi G, Khan MZ, Mullen-Przeworski A and Meucci O: Modulation of neuronal CXCR4 by the microopioid agonist DAMGO. J Neurovirol 12: 492-500, 2006.

60. Suzuki S, Chuang LF, Yau P, Doi RH and Chuang RY: Interactions of opioid and chemokine receptors: oligomerization of mu, kappa, and delta with CCR5 on immune cells. Exp Cell Res 280: 192-200, 2002.

61. Kampa M, Papakonstanti EA, Alexaki VI, Hatzoglou A, Stournaras C and Castanas E: The opioid agonist ethylketocyclazocine reverts the rapid, non-genomic effects of membrane testosterone receptors in the human prostate $\mathrm{LNCaP}$ cell line. Exp Cell Res 294: 434-445, 2004.

62. Liu B, Yu J, Taylor L, Zhou X and Polgar P: Microarray and phosphokinase screenings leading to studies on ERK and JNK regulation of connective tissue growth factor expression by angiotensin II 1a and bradykinin B2 receptors in Rat1 fibroblasts. J Cell Biochem 97: 1104-1120, 2006.

63. Prado GN, Taylor L, Zhou X, Ricupero D, Mierke DF and Polgar P: Mechanisms regulating the expression, self-maintenance, and signaling-function of the bradykinin B2 and B1 receptors. J Cell Physiol 193: 275-286, 2002. 